\section{Science and religion}

SIR - Brian Josephson's defence (Nature 362,$583 ; 1993$ ) of a scientific analysis of religion is a well intentioned attempt at a non-partisan approach to understanding the phenomenon of 'faith'. But are the resources and facilities of even the Cavendish Laboratory sufficient for the task?

Josephson unfortunately reveals his own professional presumptions. He claims that "any scientific study of religion should . . . take account of the fact that a central theme of religion .... is the attempt to maximize 'human goodness", and then bases his research proposal on that assumption. Although I personally doubt that gene therapists will ever be able to isolate and 'turn on' a (sadly too) latent 'human goodness gene', such thinking illustrates the strange hybrid of behaviourism and Platonism that characterizes much discussion of the 'scientific' analyses of 'religion'.

The central theme of most of the major world religions is not maximizing goodness per se, but achieving some given state of salvation (whether that is the Christian or Islamic notion of resurrection, or the Buddhist notion of nirvana). Religious systems and practices are understood by the faithful as simply human structures developed to teach subsequent generations about what they take to be an actual (future) physical reality. At most, maximizing human goodness is only a means to this end.

In the wake of the siege and fire at the headquarters of a religious sect in Waco, Texas, in April, when many people died, it would be too easy for the cynic to dismiss people with such strongly held metaphysical beliefs in salvation simply as suffering from dangerous collective delusions. No doubt Richard Dawkins finds some empirical support for his 'religious virus' theory in the events at Waco. However, it must be remembered that people do not commit their lives merely to received and comforting hypotheses of an afterlife (or a non-afterlife in the case of Buddhism). An individual's commitment is also based (phenomenologically) on his or her own complex personal experiences of life. Newton, Faraday and a great many contemporary scientists (and presumably many at the Waco compound too), would claim to have directly experienced a purposive, nurturing and transpersonal providence, which they have chosen to call the will of God. Dawkins' deeply held atheism, similarly, is due only to his own non-experience, or non-recognition, of such a phenomenon, resulting in consequent inability to frame an acceptable God hypothesis. Certainly psychopathological factors may affect a particular individual's response to such a phenomenon, or confuse his or her under- standing of the relationship of this phenomenon to God. Hence there is a very real need for doctrinal (non-cultic) approaches to these notions.

The scientific interpretation of physical phenomena has a vital contribution to make in the systematic analysis of the phenomenological experiences entailed in religious belief. Unfortunately, science is still considered by some to have invalidated the notion of providence, due to an incommensurability with simple linear determinism. In an era when quantum physics has made the mechanistic paradigm redundant, a comprehensive review is urgently needed of all the (psychological, sociological and physical) factors at work in the structures and apparent anomalies of religious doctrine and belief. A stubborn unwillingness to consider the possibility that certain models of a providential process may be supported by certain legitimate interpretations of physics is hardly in the tradition of disinterested scientific enquiry.

Such a research strategy is obviously beyond the competence of any individual discipline within the natural or social sciences, and perhaps the abdication of theology as the 'Queen of the Sciences' was premature after all. In this regard, and in the light of the Waco disaster, the endowment of a lectureship in theology and natural science at the University of Cambridge (see Nature 362, 380 \& 689$690 ; 1993)$ is to be welcomed by sceptical scientist and committed believer alike.

\section{Michael Houlder}

37 Argo Street,

Bolton BL36TT, UK

SIR - Just as science has its literature so does religion. The literature of science is concerned with observed facts of nature and with theories that attempt to encompass as many empirical observations as possible. The literature of religion is based mainly on interpretations of the Bible for the Judaeo-Christian religions and of the sacred works of the other religions of the world.

While the earliest attempts at explanation of the Universe were based on the thinking of the writers of the Bible and biblical scholars leading to the story of the creation in Genesis, other more scientific theories were being pronounced by Aristotle and other Greek philosophers.

However, by the end of the seventeenth century, most of this 'biblical science' had been replaced by the observations of Tycho Brahe and their interpretation by Kepler, and Newton in the fields of astronomy and mathematics. From this time onwards, science was founded on a firm empirical base while religious interpretations continued to be made on the basis of faith in sacred writings.

The existence of God is a question that has been answered in numerous ways by religious philosophers and by scientists.

The main fact that has been established in Christian religion is that the man Jesus Christ did actually exist. It is a well documented matter of history that he had an exemplary life and that his teachings formed a valuable code of moral behaviour.

A belief in God requires a step in faith which cannot be justified by pure logic. It seems that God has an existence only in the minds of men who have taken this step and in their writings. These men have created a God in their own image with no historical or scientific basis.

It is to be hoped that whoever is elected to the lecturership in science and theology at the University of Cambridge will bear these facts in mind.

\section{H. Evans}

School of Science,

Sheffield Hallam University,

Pond Street, Sheffield S1 IWB, UK

SIR - Science has its base in natural philosophy. The scope of science, by virtue of its method of study, is limited to the 'sensible' Universe. Any exploration beyond that which can be directly or indirectly measured (even if only in principle) must take with it an element of $a$ priori philosophy which cannot, in principle, be established scientifically. Outside the realm of the sensible, the scientific method of analysis has little to say. Scientists may, if they wish, postulate that there is nothing outside the sensible realm, but such theories are unprovable and, therefore, bad science.

Theology, on the other hand, explicitly allows for a God or gods whose being, partly or wholly, lies outside the scope of the sensible Universe (for example by virtue of being its Creator). Given this postulate, it is entirely reasonable to bring to bear philosophical reasoning that is not bound by the constraints of science.

It is true that there are many in both camps who vehemently contradict the views of the other, but I, as a scientist and a Christian, have my science and my religion, provided I am not required to apply scientific analysis beyond the bounds of its philosophic legitimacy. All serious thinkers should take this as a challenge to offer up examples of such obstacles.

\section{Graham L. Mathieson}

24 Courtmount Grove

Cosham, Hampshire PO6 2BL, UK

SIR - Josephson requests more scientific analysis of religion, but suggests no experiments or testable hypotheses.

There are two universal functions of religion. The most primitive is to explain the capricious nature of random events. 